\title{
Indirect quantification of lipid peroxidation in steroid responsive nephrotic syndrome
}

\author{
Sanjay Kinra, Bimbadhar Rath, Bhaskar C Kabi
}

\begin{abstract}
Aims-To test the hypothesis that oxygen free radicals are mediators of excessive protein permeability in steroid responsive nephrotic syndrome.

Design-Case control study.

Subjects-Patients: 20 children with steroid responsive nephrotic syndrome; controls: 20 children admitted for elective surgery.

Setting-The paediatric and biochemistry departments of the Maulana Azad Medical College, New Delhi, India.

Methods-Blood samples were taken twice from children with nephrotic syndrome (on admission and on urinary remission) and once from controls. Biochemical assays were carried out on these blood samples to quantify the indirect markers of free radical injury in the body, namely: vitamin $E$, reduced glutathione (GSH), glucose-6-phosphate dehydrogenase (G6PD), malonyldialdehyde (MDA), and membrane cholesterol in erythrocytes.
\end{abstract}

Results-There was some evidence supportive of oxidative injury in the children with nephrotic syndrome in the form of greatly reduced concentrations of antioxidants vitamin $\mathrm{E}(155.4 \mu \mathrm{g} / 100 \mathrm{ml}$ in controls, $86.4 \mu \mathrm{g} / 100 \mathrm{ml}$ in patients) and G6PD (364 mU/ml in controls, $205.1 \mathrm{mU} /$ $\mathrm{ml}$ in patients). However, concentrations of the oxidation byproduct MDA were raised only in the remission phase of the disease $(0.984 \mathrm{nmol} / \mathrm{ml}$ in controls, $1.158 \mathrm{nmol} / \mathrm{ml}$ in cases), whereas those of GSH were unaltered.

Conclusions-Changes in the concentrations of MDA, G6PD, and vitamin $E$ are consistent with increased amounts of oxidation in steroid responsive nephrotic syndrome. Further research is needed to explain whether these changes are a cause or consequence of the disease.

(Arch Dis Child 2000;82:76-78)

Keywords: steroid responsive nephrotic syndrome; free radicals; vitamin E; glucose-6-phosphate dehydrogenase

Minimal change nephrotic syndrome, which accounts for approximately $80 \%$ of childhood nephrotic syndrome, generally responds well to treatment with corticosteroids. ${ }^{1}$ The exact pathogenesis of excessive protein permeability remains unclear, but altered immunological and genetic mechanisms have all been proposed. ${ }^{2-7}$ An important advance in under- standing the pathogenesis of this disease was the observation that oxygen free radicals are possible mediators of injury in aminonucleoside nephrosis in rats. ${ }^{8}$ The similarity of this animal model to human minimal change nephrotic syndrome gave birth to the idea that free radical mediated injury could play a role in the pathogenesis of this disorder. The extremely short half life of free radicals means that they cannot be measured directly and that oxidative activity must be measured indirectly by the levels of antioxidant substances in the body. Peroxidation of the lipid membranes raises the concentrations of their byproduct malonyldialdehyde (MDA) and the consequent lowering of antioxidants as a result of consumption. ${ }^{9}{ }^{10}$ The study of Gusmano and colleagues ${ }^{11}{ }^{12}$ lent support to the hypothesis of free radical mediated injury by documenting high concentrations of MDA and reduced concentrations of the antioxidant glutathione (GSH) in the red blood cells of children with nephrotic syndrome. In Gusmano's study, however, half the patients were steroid unresponsive and there was no information about the status of other antioxidants. The concentrations of MDA in the steroid responsive patient subgroup were also unaltered. These factors and the absence of subsequent work confirming their results prompted us to undertake this study.

\section{Subjects and methods}

The patients were children admitted with the clinical diagnosis of nephrotic syndrome satisfying the ISKDC (international study of kidney disease in children) criteria. ${ }^{1}$ A total of 24 consecutive patients were enrolled over a period of one year. Those who did not respond $(\mathrm{n}=1)$ to a standard regimen of corticosteroids, ${ }^{1}$ or who were lost to follow up ( $n=1)$, were excluded, as were children with acute infection or medication in the week before admission $(n=2)$. Children admitted for elective general surgery to the same hospital served as controls. All the cases were treated with prednisolone. Blood samples were taken once from controls and twice from patients, once on admission and again at urinary remission. Repeat samples were carried out within one week of remission. Vitamin E ( $\alpha$-tocopherol), GSH, glucose-6phosphate dehydrogenase (G6PD), MDA, and membrane cholesterol concentrations in the red blood cells were measured.

Venous blood $(5 \mathrm{ml}$ ) was collected in clean dried EDTA bottles and stored immediately at $4^{\circ} \mathrm{C}$. All measurements were made within six hours of sample collection. A red blood cell suspension, obtained after centrifugation, was washed three times with five volumes of 
Table 1 Summary of the concentrations of various compounds in the red blood cells of patients and controls

\begin{tabular}{llll}
\hline & & \multicolumn{2}{l}{ Patients } \\
\cline { 2 - 4 } & Controls & Acute phase & Remission phase \\
\hline MDA $(\mathrm{nmol} / \mathrm{ml})$ & $0.98(0.04)$ & $1.20(0.09)$ & $1.16(0.07)$ \\
$\mathrm{GSH}(\mathrm{mg} / 100 \mathrm{ml})$ & $53.5(1.67)$ & $49.25(2.09)$ & $52.7(2.72)$ \\
Vitamin $(\mu \mathrm{g} / 100 \mathrm{ml})$ & $155.4(10.67)$ & $86.4(4.49)$ & $108.85(8.25)$ \\
Cholesterol $(\mathrm{mg} / 100 \mathrm{ml})$ & $43.5(1.61)$ & $52.4(1.95)$ & $50.5(1.91)$ \\
G6PD $(\mathrm{mU} / \mathrm{ml})$ & $363.95(13.98)$ & $205.05(13.82)$ & $230.9(14.2)$ \\
\hline
\end{tabular}

Values are mean (SE).

G6PD, glucose-6-phosphate dehydrogenase; GSH, reduced glutathione; MDA, malonyldialdehyde.

isotonic saline and then reconstituted to a final haematocrit of $50 \%$. The suspended red blood cells were used to assess the various parameters by standard biochemical methods as follows: (1) vitamin $\mathrm{E}$ was estimated by extraction to an organic solvent ${ }^{13}$; (2) GSH was estimated by assaying the sulfhydryl content of erythrocytes $^{14}$; (3) G6PD was estimated by measuring the rise in extinction of NADPHH $+{ }^{15}$; (4) membrane cholesterol was estimated by extracting the cholesterol to a choloroform/isopropanol mixture ${ }^{16}$; and MDA was estimated by its thiobarbituric reactivity. ${ }^{17}$ Baseline investigations were carried out in all the patients including blood counts, urea, creatinine, cholesterol, C3, 24 hour urinary protein, serum protein, and infection screen including blood and urinary cultures.

\section{STATISTICS}

Data from 20 patients and an equal number of controls were analysed. The controls were only frequency matched for age and sex. Student's $t$ tests (paired and unpaired) were used to test for significant differences between the means (at $5 \%$ level).

\section{Results}

The mean age of children with nephrotic syndrome was 6.7 years (range, 2-12 years) and the mean age of controls was 7.1 years (range, 2-12 years). The boy to girl ratio was 4:1 for patients and 3:1 for controls. Seven patients were admitted in their first attack, the remainder were relapsers. Microscopic haematuria was present in two cases and hypertension was present in one. None of the patients was azotaemic. The patients were slightly more anaemic (mean haemoglobin, $102 \mathrm{~g} / 1$; range, 75-112) compared with the controls (mean haemoglobin, $131 \mathrm{~g} / \mathrm{l}$; range, 125-160). The mean duration of second sampling after the first sampling was 33.5 days (range, 14-82).

Table 1 provides a summary of the results of various parameters and table 2 summarises the differences between the means. Vitamin E (controls, $155.4 \mu \mathrm{g} / 100 \mathrm{ml}$; patients, $86.4 \mu \mathrm{g} /$ $100 \mathrm{ml} ; \mathrm{p}<0.001$ ) and G6PD (controls, $364 \mathrm{mU} / \mathrm{ml}$; patients, $205.1 \mathrm{mU} / \mathrm{ml}$; $\mathrm{p}<0.001$ ) were both significantly lower in patients with nephrotic syndrome when compared with the controls. This difference between the controls and patients persisted (although it was reduced) even when the disease went into remission. MDA concentrations were significantly higher in patients compared with controls only in the remission phase of the disease (controls, $0.98 \mathrm{nmol} / \mathrm{ml}$; patients, $1.16 \mathrm{nmol} / \mathrm{ml} ; \mathrm{p}=0.035)$. Reduced glutathione concentrations were no different between the patients and controls. Cholesterol values were significantly higher in the patients compared with controls, but fell slightly during remission.

\section{Discussion}

Our findings, by virtue of a combination of lowered G6PD and vitamin E concentrations along with raised MDA values, are consistent with increased oxidation in steroid responsive nephrotic syndrome.

G6PD and vitamin E are two of the key antioxidants in the body and their concentrations fall, as expected, in the acute phase of nephrotic syndrome, as a result of increased neutralisation in neutralising excessive oxidant stress. When the oxidant stress of the acute phase is over, there is less utilisation of the antioxidants, and hence the concentrations of vitamin $\mathrm{E}$ rise during remission. In the case of G6PD, however, they remain fairly low. It is possible that this could be the result of slow regeneration of the enzyme, the time of the second sampling being too short after induction of remission to observe a significant change. It is possible to have such low G6PD values without noticeable haemolytic disorder. However, one recent study (Mathew J et al, personal communication, 1997) has shown increased osmotic fragility in children with nephrotic syndrome.

Similar to the findings of Gusmano et al, ${ }^{11}{ }^{12}$ our study failed to demonstrate significantly raised MDA values in the acute phase of steroid responsive nephrotic syndrome. The slightly

Table 2 Differences between the mean concentrations (95\% confidence intervals) of various compounds in the red blood cells of patients and controls

\begin{tabular}{|c|c|c|c|}
\hline & \multicolumn{2}{|l|}{ Controls minus patients } & \multirow[b]{2}{*}{ Acute minus remission phase (cases) } \\
\hline & Acute phase & Remission phase & \\
\hline $\operatorname{MDA}(\mathrm{nmol} / \mathrm{ml})$ & $\begin{array}{l}-0.14(-0.33 \text { to } 0.05) \\
p=0.15\end{array}$ & $\begin{array}{l}-0.18(-0.34 \text { to }-0.02) \\
p=0.035\end{array}$ & $\begin{array}{l}-0.04(-0.26 \text { to }+0.18) \\
p=0.73\end{array}$ \\
\hline $\mathrm{GSH}(\mathrm{mg} / 100 \mathrm{ml})$ & $\begin{array}{l}4.25(-1.0 \text { to } 9.5) \\
p=0.12\end{array}$ & $\begin{array}{l}0.8(-5.45 \text { to } 7.05) \\
p=0.79\end{array}$ & $\begin{array}{l}-3.45(-10.23 \text { to }+3.33) \\
\mathrm{p}=0.32\end{array}$ \\
\hline Vitamin $\mathrm{E}(\mu \mathrm{g} / 100 \mathrm{ml})$ & $\begin{array}{l}69(46.32 \text { to } 91.68) \\
p<0.001\end{array}$ & $\begin{array}{l}46.55(20.13 \text { to } 72.97) \\
p=0.002\end{array}$ & $\begin{array}{l}-22.45(-4.05 \text { to }-40.85) \\
\mathrm{p}=0.02\end{array}$ \\
\hline Cholesterol (mg/100 ml) & $\begin{array}{l}-8.9(-3.94 \text { to }-13.86) \\
p=0.002\end{array}$ & $\begin{array}{l}-7.0(-2.09 \text { to }-11.91) \\
\mathrm{p}=0.008\end{array}$ & $\begin{array}{l}+1.9(-3.46 \text { to }+7.26) \\
p=0.50\end{array}$ \\
\hline G6PD (mU/ml) & $\begin{array}{l}58.45(119.93 \text { to } 196.97) \\
\mathrm{p}<0.001\end{array}$ & $\begin{array}{l}133.05(94 \text { to } 172.1) \\
\mathrm{p}<0.001\end{array}$ & $\begin{array}{l}-25.85(-64.69 \text { to }+12.99) \\
p=0.20\end{array}$ \\
\hline
\end{tabular}

G6PD, glucose-6-phosphate dehydrogenase; GSH, reduced glutathione; MDA, malonyldialdehyde. 
raised MDA concentrations reached borderline significance only in the remission phase. We are unclear about the reason for such a lag period or the presence of such a weak response. It could be because of lack of power in our study (small sample size) or bias resulting from selection of hospital controls. It is possible that the much higher concentrations of membrane cholesterol found in the acute phase, by virtue of its protective effect, could account for the small rise in MDA. Falling concentrations of red blood cell membrane cholesterol during the remission phase could enable enhanced peroxidation to occur thereafter.

Gusmano and colleagues ${ }^{11}{ }^{12}$ found significantly lower red blood cell GSH concentrations (in both steroid responsive and nonresponsive subgroups independently), which we could not confirm in our study. Although GSH concentrations were lower in patients than controls, this did not reach significance. A total of 10 patients in the Gusmano study had steroid responsive disease and such a small patient number could have resulted in an anomalous finding. However, it is possible that even twice the number of patients in our study might have been insufficient to demonstrate a difference in concentrations of GSH between the patients and controls. Another possible explanation is a difference in the free radical load in the two sets of patients, leading to a differential utilisation of the various antioxidants.

Despite significantly lower concentrations of G6PD and vitamin E, a lack of convincing alterations in the concentrations of MDA and GSH means that only limited support can be given to the concept of oxidative injury as a possible mechanism of proteinuria in children suffering from steroid sensitive nephrotic syndrome. It is also difficult to conclude whether such changes are part of the mechanism that causes proteinuria in steroid responsive nephrotic syndrome or are a conse- quence of the disease. Further studies, using larger numbers of patients, are needed to understand the relevance of these findings.

We are grateful to all the children who participated in the study and their parents for their support.

1 International Study of Kidney Disease in Children. The primary nephrotic syndrome in children. Identification of patients with minimal change nephrotic syndrome from initial response to prednisone. $\mathcal{F}$ Pediatr 1981;98:561-4.

2 Chan MK, Chan KW, Jones B. Immunoglobulins (IgG, IgA, IgM, IgE) and complement components $(\mathrm{C} 3, \mathrm{C} 4)$ in nephrotic syndrome due to minimal change and other forms of glomerulonephritis, a clue for steroid therapy? Nephron 1987;47:125-30.

3 Fiser RT, Arnold WC, Charlton RK, Steele RW, Childress $\mathrm{SH}$, Shirkey B. T-lymphocyte subsets in nephrotic synrome. Kidney Int 1991;40:913-16.

4 Gianiacomo J, Cleary TG, Cole BR, Hoffsten P, Robson AM. Serum immunoglobulin in nephrotic syndrome (a possible cause of minimal change nephrotic synrome). $N$ Engl f Med 1975;293:8-12.

5 Lagrue G, Laurent J, Hirbec G, et al. Serum IgE in primary glomerular diseases. Nephron 1984;36:5-9.

6 Matsumoto K, Osakabe K, Katayama H, Hatano M. In vitro ymphocyte dysfunction in lipoid nephrosis. Nephron 1982; 34:220-3.

7 Matsumoto K, Osakabe K, Katayama H, Okano K, Hatano M. Defective cell mediated immunity in lipoid nephrosis. Int Arch Allergy Appl Immunol 1984;73:370-2.

8 Diamond JR, Bonventre JV, Karnovsky MJ. A role for oxygen free radicals in aminonucleoside nephrosis. Kidney oxygen free radicals
Int $1986 ; 29: 478-83$.

9 Freeman BA, Crapo JD. Biology of disease: free radicals and tissue injury. Lab Invest 1982;47:412-26.

10 Pryor WA The role of free radical reactions in biological systems. In: Pryor WA, ed. Free radicals in biology. New York: Academic Press, 1976:1-50

11 Gusmano R, Ginveri F, Chiggeri GH, et al. Intraerythrocytary markers of peroxidative alteration in children with nephrotic syndrome. Contrib Nephrol 1988;67:99-102.

12 Ginevri F, Ghiggeri GM, Candiano G, et al. Peroxidative damage of the erythrocyte membrane in children with nephrotic syndrome. Pediatr Nephrol 1989;3:25-32.

13 Kayden H, Bjornson L. The dynamics of Vitamin E transport in the human erythrocyte. Ann N Y Acad Sci 1972;203:127-40.

14 Beutler E, Durm O, Kelly BM. Improved methods for determination of blood glutathione. F Lab Clin Med 1963; 61:882-8.

15 Kornberg A, Horecker BL. Glucose-6-phosphate dehydrogenase. In: Colowick SP, Kaplan NO, eds. Methods in enzymology, Vol 1. New York: Academic Press, 1955:323-6.

16 Rose HG, Oklander M. Improved procedure for the extraction of lipids from human erythrocytes. F Lipid Res 1965;6: $428-31$

17 Stocks J, Dormandy TL. The autoxidation of human red cell lipids induced by hydrogen peroxide. Br $\mathcal{F}$ Haematol 1971;20:95-112. 